\title{
Multinational Capital Structure and Tax Competition
}

\author{
Matthias Wrede
}

CESIFO WORKING PAPER No. 3041

CATEgory 1: Public FinANCE

APRIL 2010

\footnotetext{
An electronic version of the paper may be downloaded

- from the SSRN website:

- from the RePEc website:

- from the CESifo website:

www.SSRN.com

www.RePEc.org

www.CESifo-group.org/wp
} 


\title{
Multinational Capital Structure and Tax Competition
}

\begin{abstract}
This paper analyzes tax competition when welfare maximizing jurisdictions levy source-based corporate taxes and multinational enterprises choose tax-efficient capital-to-debt ratios. Under separate accounting, multinationals shift debt from low-tax to high-tax countries. The Nash equilibrium of the tax competition game is characterized by underprovision of publicly provided goods. Under formula apportionment, the country-specific capital-to-debt ratio of a multinational's affiliate is independent of the jurisdiction's tax rate. Public good provision is either too large or too small. If the debt externality is not negative, there is clearly underprovision under formula apportionment.
\end{abstract}

JEL-Code: F23, H25, H42, H73.

Keywords: multinational enterprises, financial policy, profit shifting, corporate taxation, tax competition.

\author{
Matthias Wrede \\ University of Marburg \\ Faculty of Business Administration and Economics \\ Am Plan 2 \\ 35032 Marburg \\ Germany \\ wrede@wiwi.uni-marburg.de
}

This version: April 2010 


\section{Introduction}

Economic theory and empirical evidence suggest that multinationals shift profits from hightax to low-tax countries, especially by means of debt financing and transfer pricing. There is convincing evidence from micro data that profit shifting is sizeable (see, e.g., Mintz and Smart, 2004; Devereux, 2006; Dischinger, 2007; Weichenrieder, 2009) and that it implies a significant loss in tax revenue for high-tax countries (see Huizinga and Laeven, 2008). In the past, literature on income shifting focussed on transfer pricing, but more recently Mintz and Smart (2004), Huizinga, Laeven, and Nicodeme (2008), Schindler and Schjelderup (2008) and Haufler and Runkel (2009) have developed theoretical models of the tax-efficient debt financial policies of multinationals. Desai, Foley, and Hines (2004) discovered that U.S. multinationals alter the overall level and composition of debt in response to tax incentives, internal finance being particularly sensitive to tax differences. Huizinga, Laeven, and Nicodeme (2008) observe for European multinational firms that the leverage ratio is more sensitive to taxation on account of international debt shifting than it is for stand-alone domestic firms. Egger, Eggert, Keuschnigg, and Winner (2009) find that foreign-owned European firms on average exhibit a significantly higher debt ratio than their domestically owned counterparts in the host country and that the gap in the debt ratio increases with the host country's statutory corporate tax rate.

Governments respond to income shifting behavior by changing the tax code and the tax rate. Haufler and Schjelderup (2000) argue that income shifting may induce governments to eliminate investment allowances in an effort to offset revenue losses, thus increasing the effective tax rates on capital. Mintz and Smart (2004) and Hong and Smart (2007) point out that international tax planning may reduce tax burdens on mobile capital and so facilitate investment that can offset the negative consequences of lost revenue. This conjecture is empirically confirmed by Overesch (2009) who, based on a panel of German inbound investments, finds a positive tax response of real investments with a decreasing tax rate in the foreign direct investor's home country. In response to sizeable profit shifting,

the European Commission suggested a transition from separate accounting to a common tax base and formula apportionment (see European Commission, 2001). Although the idea seems like a good one at first glance, since its inception the proposed benefits, namely 
a reduction in compliance costs, tax planning, and tax competition, have been seriously challenged (see, for an overview, Fuest, 2008).

Ever since Zodrow and Mieszkowski (1986), it is well known that tax competition leads to underprovision of public goods when jurisdictions cannot use the full set of tax instruments. When firms can shift profits from high-tax to low-tax countries without relocating capital, tax rates may be too high (see Eichner and Runkel, 2008; Nielsen, RaimondosMoeller, and Schjelderup, 2010). Harmonizing the tax base and employing formula apportionment does not solve the problem of inefficient public good supply. Scholars reach various conclusions as to whether there is under- or overprovision under formula apportionment. According to Nielsen, Raimondos-Moeller, and Schjelderup (2010), the positive fiscal externality of taxation and the negative aggregate investment externality are responsible for this ambiguity. Pethig and Wagener (2007) argue that equilibrium tax rates are too low for property-share apportionment but tend to be too high for other formulas. Eichner and Runkel (2008) unambiguously find underprovision. Kolmar and Wagener (2007) claim that tax competition leads to suboptimally low tax rates if and only if the investment elasticity of the tax base is lower than the investment elasticity of the apportionment factor. When jurisdictions can appropriately tax residents, tax competition does not distort the public good supply. This has been shown for the standard model of tax competition by Bucovetsky and Wilson (1991) and has been confirmed for formula apportionment by Eggert and Schjelderup (2003).

This paper aims at extending previous analyses of corporate tax competition under separate accounting and formula apportionment when firms are able to shift profits from high-tax to low-tax countries via debt financing. It sets up a many-region general equilibrium model of multinational firms that make decisions regarding employment, investment, and leverage ratios. The symmetric Nash equilibrium of welfare-maximizing countries engaged in corporate tax competition is analyzed. In the main part of the paper, only external debt is considered. By external borrowing, firms benefit from the tax shield of interest deduction. However, implicitly even external borrowing involves profit shifting, since an increase in one country's tax rate decreases the common interest rate and, therefore, the value of the tax shield in any other country. This leads the subsidiaries in in the other countries to reduce borrowing. As a consequence, ceteris paribus taxable profits in 
other countries increase relative to the profit in the country where the tax rate has been increased. However, as an extension of the basic model, internal debt is added to the set of the firm's instruments. However, since external and internal debt are close substitutes, internal debt does not affect the main results qualitatively.

The approach of this contribution differs from the extant literature on tax competition in several ways:

1. In contrast to most papers on this topic which assume revenue-maximizing governments (see, e.g., Pethig and Wagener, 2007; Kolmar and Wagener, 2007; Eichner and Runkel, 2008), this paper analyzes the strategies of welfare-maximizing governments. Private consumption effects, as well as revenue effects, are considered.

2. Previous papers on corporate tax competition considers decreasing returns to scale technology (see, e.g., Pethig and Wagener, 2007; Eichner and Runkel, 2008); however, this paper assumes linearly homogeneous production functions. Since corporate taxes are distorting as long as equity is not fully deductible, even with constant returns to scale economic profits are non-zero.

3. Following Eichner and Runkel (2008), the total stock of capital is fixed, but the return to capital is endogenous. Most other papers consider the small-country case where the return to capital is exogenous (see, e.g., Wellisch, 2004; Pethig and Wagener, 2007; Pinto, 2007; Riedel and Runkel, 2007; Nielsen, Raimondos-Moeller, and Schjelderup, 2010).

4. Most papers treat profit shifting as an additive-separable component of profits (see, e.g., Riedel and Runkel, 2007; Eichner and Runkel, 2008). This paper takes a different approach by explicitly modeling the debt policy of multinationals where debt is an implicit profit shifting device leading to complex interactions with investment.

In short, this paper sets up a more general model than do previous papers. The main results can be summarized as the following:

1. Symmetric Nash equilibria of tax competition games are generically inefficient under separate accounting as well as under formula apportionment. 
2. Tax competition under separate accounting always leads to underprovision of public goods; however, overprovision cannot be ruled out under formula apportionment. Nevertheless, under apportionment, underprovision will occur unambiguously when a unilateral tax rate increase reduces debt in neighboring countries, thereby increasing the neighbors' tax base.

3. If leverage ratios are exogenously given, underprovision is the unambiguous outcome of tax competition even under formula apportionment.

Pinto (2007) and Nielsen, Raimondos-Moeller, and Schjelderup (2010) analyze tax competition in a small, open federation framework where governments maximize the welfare of their citizens. Pinto (2007) focuses on formula apportionment only. Nielsen, RaimondosMoeller, and Schjelderup (2010) compare separate accounting and formula apportionment using a rather simple profit-shifting mechanism and consider only capital-share-based formulas; they could not establish underprovision under separate accounting. Furthermore, Nielsen, Raimondos-Moeller, and Schjelderup (2010) do not consider locally captured income in their welfare analysis.

The paper is organized as follows. Section 2 develops the basic model and describes its general features. Sections 3 and 4 analyze market equilibria and equilibria of the tax competition game under separate accounting and formula apportionment, respectively. Section 5 discusses the results by comparing them briefly, on the one hand, with the benchmark without profit shifting and, on the other hand, with the policy outcome when internal debt is explicitly modeled. Section 6 concludes.

\section{The model}

I consider an economy having $n$ identical jurisdictions, with $n \geq 2$, where the population in each jurisdiction is normalized to 1 . There are a great many identical multinational enterprises (MNEs) operating a plant in each jurisdiction. These firms produce a private good with a constant returns to scale technology. Since the production function is linearly homogenous, the number of firms and output per firm are indeterminate. Without loss of generality, I proceed as if the total output is produced by a single representative MNE that 
behaves competitively. It employs $K_{i}$ units of capital and $L_{i}$ units of labor in jurisdiction $i$ to produce $F\left(K_{i}, L_{i}\right)$ units of output whose price is normalized to 1 . Marginal productivity of any input is positive and decreasing: $F_{K}>0, F_{L}>0, F_{K K}<0$, and $F_{L L}<0 .{ }^{1}$ Since the production function is linearly homogenous, $F=F_{K} K+F_{L} L$ and $F_{K L}=-F_{K K} K / L>0$. By assuming that marginal products of capital become rather large when capital intensity approaches 0, it is ensured that the MNE will indeed produce in all jurisdictions. For example, the Inada conditions would guarantee this. The wage in jurisdiction $i$ is denoted by $w_{i}$; the common return to capital by $r$.

The MNE maximizes total profits net of corporate taxes, П. Each jurisdiction levies a source-based tax on corporate income while exempting foreign-source income of domestic residents. The firm finances investment with equity $E_{i}$ and debt $D_{i}: K_{i}=E_{i}+D_{i}$, the debt-to-capital ratio in jurisdiction $i$ is denoted $\alpha_{i}=D_{i} / K_{i}$. Equity is not deductible, but debt is fully deductible from tax liabilities in every jurisdiction. In accordance with most of the literature, I assume that costs per unit of capital $C\left(\alpha_{i}\right)$ are associated with borrowing, with $C(0)=C^{\prime}(0)=0, C^{\prime}\left(\alpha_{i}\right) \geq 0, C^{\prime \prime}\left(\alpha_{i}\right)>0$, and $\lim _{\alpha \rightarrow 1} C^{\prime}(\alpha)=\infty$. These costs reflect increasing bankruptcy risks and bankruptcy costs. ${ }^{2}$ In my basic model, all debt is external debt; internal debt is discussed as an extension. However, regardless of whether debt is internal or external, the MNE will shift debt toward high-tax countries, as will be shown later. The economic profit in jurisdiction $i$ is output minus labor costs and capital costs including borrowing costs:

$$
\pi_{i}=F\left(K_{i}, L_{i}\right)-w_{i} L_{i}-\left[r+C\left(\alpha_{i}\right)\right] K_{i}, \quad i=1, \ldots, n
$$

Taxable profits in jurisdiction $i$ differ from economic profits, since only borrowing costs are deductible:

$$
\pi_{i}^{t}=F\left(K_{i}, L_{i}\right)-w_{i} L_{i}-r \alpha_{i} K_{i}, \quad i=1, \ldots, n
$$

In this model, I assume without loss of generality that borrowing costs are not tax deductible. Including borrowing costs in the tax base would not change the results qualita-

\footnotetext{
${ }^{1}$ Partial derivatives are indicated by a subscript.

${ }^{2}$ In my model, the optimum leverage ratio in a tax-free world would be $0 . \quad$ I could easily introduce a strictly positive benchmark leverage ratio without affecting qualitative results, see Schindler and Schjelderup (2008) and Haufler and Runkel (2009).
} 
tively.

Capital is perfectly mobile, labor is inelastically supplied and perfectly immobile. Each jurisdiction is endowed with $\bar{K}$ units of capital and $\bar{L}$ units of labor. The common return to capital $r$ is determined so as to clear the capital market in all jurisdictions; the wage $w_{i}$ clears the labor market in jurisdiction $i$. The capital market clearing condition is

$$
\sum_{i=1}^{n}\left(K_{i}-\bar{K}\right)=0
$$

the labor markets clear at

$$
L_{i}-\bar{L}=0, \quad i=1, \ldots, n
$$

The representative individual in jurisdiction $i$ derives utility from private consumption $X_{i}$ and a publicly provided good $G_{i}$. The utility function $U\left(X_{i}, G_{i}\right)$ exhibits positive and diminishing marginal utilities and is strictly quasi-concave. To exclude corner solutions, I assume that marginal utilities are sufficiently large when private and public consumption approaches 0 . The representative individual in jurisdiction $i$ owns one share of the MNE, and earns capital and labor income. The budget constraint reads:

$$
X_{i}=\frac{\Pi}{n}+r \bar{K}+w_{i} \bar{L}, \quad i=1, \ldots, n .
$$

The government of jurisdiction $i$ pays for the provision of good $G_{i}$ with its tax revenue $T_{i}$. The marginal rate of transformation between the private and the publicly provided good is constant and normalized to $1: G_{i}=T_{i}$. National governments set tax rates noncooperatively to maximize the welfare of their citizens $U\left(X_{i}, G_{i}\right)$. The timing is as follows:

1. National governments simultaneously set tax rates $t_{i}, 0 \leq t_{i} \leq 1, i=1, \ldots, n$.

2. National wages and the common interest rate are determined such that the MNE maximizes its profits through choice of labor demand, capital demand, and debt, and markets clear.

Nash equilibria are determined by the government's first-order conditions:

$$
\frac{\partial U\left(X_{i}, G_{i}\right)}{\partial X_{i}} \frac{d X_{i}}{d t_{i}}+\frac{\partial U\left(X_{i}, G_{i}\right)}{\partial G_{i}} \frac{d T_{i}}{d t_{i}}=0, \quad i=1, \ldots, n
$$


The marginal rate of substitution between private and public consumption is equal to the perceived marginal rate of transformation:

$$
\frac{\partial U\left(X_{i}, G_{i}\right) / \partial G_{i}}{\partial U\left(X_{i}, G_{i}\right) / \partial X_{i}}=-\frac{d X_{i} / d t_{i}}{d T_{i} / d t_{i}}, \quad i=1, \ldots, n
$$

I focus only on symmetric Nash equilibria of the tax-competition game where all jurisdictions set the same tax rate. A symmetric equilibrium is characterized by $K_{i}=K$, $L_{i}=L, w_{i}=w, D_{i}=D, \alpha_{i}=\alpha, t_{i}=t, X_{i}=X$, and $G_{i}=G$, for $i=1, \ldots, n$.

Unilateral tax rate changes give rise to two types of externalities, a private consumption externality (PCE) and a public good externality (PGE):

$$
\mathrm{PCE}=(n-1) \frac{d X_{j}}{d t_{i}} \text { and } \mathrm{PGE}=(n-1) \frac{d T_{j}}{d t_{i}} .
$$

\section{Separate accounting}

Market equilibrium Under separate accounting, the tax base in jurisdiction $i$ is the taxable profit $\pi_{i}^{t}$. The MNE solves

$$
\max _{K_{i}, L_{i}, D_{i}} \Pi^{S A}:=\sum_{j=1}^{n}\left(\pi_{j}-t_{j} \pi_{j}^{t}\right) \quad \text { s.t. } E_{i} \geq 0, \quad i=1, \ldots, n .
$$

Since the marginal costs of borrowing approach infinity as the debt-to-capital ratio approaches 1 , the non-negativity constraints will never be binding. The market equilibrium is characterized by the first-order conditions with respect to labor demand, debt, and investment for $i=1, \ldots, n$

$$
\begin{aligned}
& F_{L}\left(K_{i}, L_{i}\right)-w_{i}=0, \\
& t_{i} r-C^{\prime}\left(\alpha_{i}\right)=0, \\
& \left(1-t_{i}\right) F_{K}\left(K_{i}, L_{i}\right)-r-C\left(\alpha_{i}\right)+\alpha_{i} C^{\prime}\left(\alpha_{i}\right)=0,
\end{aligned}
$$

and the market-clearing conditions of Equations (3) and (4). Since labor costs are fully deductible, the marginal product of labor is equal to the wage rate. The firm's affiliate increases debt until marginal costs of borrowing are equal to tax refunds. Rewriting Equation (12) and using Equation (11),

$$
F_{K}^{i}=r \frac{1-\alpha_{i} t_{i}}{1-t_{i}}+\frac{C\left(\alpha_{i}\right)}{1-t_{i}}>r,
$$


it is obvious that the user cost of capital exceed the return to capital $r$; thus there are incentives to underinvest. Holding the return to capital fixed, and taking Equation (11) into account by setting $d \alpha_{i} / d t_{i}=r / C^{\prime \prime}\left(\alpha_{i}\right)$, it follows that $d F_{K}^{i} / d t_{i}>0$. Underinvestment is more severe in high-tax countries than in low-tax countries.

Plugging first-order conditions into the definitions for profits and taking linear homogeneity into account yields

$$
\pi_{i}=t_{i} \pi_{i}^{t}, \quad \text { and } \quad \pi_{i}^{t}=\left(F_{K}^{i}-\alpha_{i} r\right) K_{i}, \quad i=1, \ldots, n
$$

Economic profits and taxable profits are non-zero, since the rental rate of capital $r$ falls short of the user cost of capital $F_{K}^{i}$. However, as a consequence of constant returns to scale, profits net of corporate taxes are zero in every jurisdiction.

From the first-order conditions and the market clearing conditions, the impact of taxation on investment, borrowing, wages, and the interest rate can be calculated in a symmetric equilibrium for $i=1, \ldots, n$ and $j \neq i$ :

$$
\begin{aligned}
& \frac{d K_{j}}{d t_{i}}=-\frac{F_{K}-\alpha r}{n(1-t) F_{K K}}>0, \quad \frac{d K_{i}}{d t_{i}}=-(n-1) \frac{d K_{j}}{d t_{i}}<0, \\
& \frac{d w_{j}}{d t_{i}}=\frac{\left(F_{K}-\alpha r\right) K}{n(1-t) L}>0, \quad \frac{d w_{i}}{d t_{i}}=-(n-1) \frac{d w_{j}}{d t_{i}}<0, \\
& \frac{d r}{d t_{i}}=-\frac{F_{K}-\alpha r}{n(1-\alpha t)}<0, \quad \frac{d \alpha_{j}}{d t_{i}}=\frac{t}{C^{\prime \prime}} \frac{d r}{d t_{i}}<0, \quad \frac{d \alpha_{i}}{d t_{i}}=\frac{1}{C^{\prime \prime}}\left(t \frac{d r}{d t_{i}}+r\right), \\
& \frac{d(n D)}{d t_{i}}=\frac{1}{C^{\prime \prime}}\left(n t \frac{d r}{d t_{i}}+r\right) .
\end{aligned}
$$

In response to an increase in one country's tax rate, firms shift capital abroad, which, due to labor-capital complementarity, reduces wages in the country that raised taxes and increases wages abroad. The increase in the tax rate also implies higher user cost of capital, which mitigates investment incentives and, eventually, reduces the return to capital. A lower return to capital reduces tax savings abroad and, thus, the debt-to-capital ratio. In the country that raised taxes, the MNE will raise the debt-to-capital ratio if direct tax savings exceed the dampening interest rate effect, an effect that becomes more likely as the number of countries involved increases. Total debt $n D$ will shrink in response to a unilateral increase in the tax rate if and only if the tax-rate elasticity of the interest rate, $\eta:=-\left(d r / d t_{i}\right)(t / r)$ is larger than $1 / n$ which is equivalent to $t>r / F_{k}$. Hence, if the tax 
rate is large relative to the ratio of the interest rate and the user cost of capital, for the economy as a whole interest-rate reduction dominates the direct tax rate effect. Note that this condition is independent of the number of countries $n$.

Tax competition Since profits are zero, individual income effectively consists only of capital and labor income, $X_{i}=r \bar{K}+w_{i} \bar{L}$. Hence, the impact of a unilateral tax rate increase on private consumption is given by

$$
\frac{d X_{i}}{d t_{i}}=\frac{d r}{d t_{i}} \bar{K}+\frac{d w_{i}}{d t_{i}} \bar{L}=\frac{K\left(F_{K}-\alpha r\right)[t(1-\alpha)-n(1-\alpha t)]}{n(1-t)(1-\alpha t)}<0, \quad i=1, \ldots, n,
$$

where symmetry is taken into account. Furthermore, tax revenue in jurisdiction $i$ is

$$
T_{i}=t_{i} K_{i}\left[F_{K}\left(K_{i}, L_{i}\right)-\alpha_{i} r\right], \quad i=1, \ldots, n,
$$

implying in a symmetric set-up

$$
\frac{d T_{i}}{d t_{i}}=\left(F_{K}-\alpha r\right)\left(K+t \frac{d K_{i}}{d t_{i}}\right)+t K\left(F_{K K} \frac{d K_{i}}{d t_{i}}-\alpha \frac{d r}{d t_{i}}-r \frac{d \alpha_{i}}{d t_{i}}\right), \quad i=1, \ldots, n .
$$

Inserting and rearranging leads to

$$
\frac{d T_{i}}{d t_{i}}=\frac{\Psi}{C^{\prime \prime} F_{K K} n(1-t)(1-\alpha t)}, \quad i=1, \ldots, n,
$$

where

$$
\begin{aligned}
\Psi & =F_{K K} K r(1-t) t\left[\left(F_{K}-\alpha r\right) t-n r(1-\alpha t)\right] \\
& +C^{\prime \prime}\left(F_{K}-\alpha r\right)\left\{(n-1)\left(F_{K}-\alpha r\right) t(1-\alpha t)+F_{K K} K[n(1-\alpha t)-(1-\alpha) t]\right\} .
\end{aligned}
$$

Since $d X_{i}, d t_{i}<0$, the Nash equilibrium is at the left-hand side of the perceived Laffer curve where $\Psi$ must be negative. Equations (16) and (19), together with Equations (6), determine the Nash equilibrium of tax competition under separate accounting. To discover whether jurisdictions would benefit from cooperating on tax rates, I determine the impact of coordinated tax rate changes for $i=1, \ldots, n$ :

$$
\begin{aligned}
& \frac{d X_{i}}{d t_{i}}+(n-1) \frac{d X_{i}}{d t_{j}}=n \frac{d r}{d t_{i}} \bar{K} \\
& \frac{d T_{i}}{d t_{i}}+(n-1) \frac{d T_{i}}{d t_{j}}=\left(F_{K}-\alpha r\right) K-t K\left[n \alpha \frac{d r}{d t_{i}}+r\left(\frac{d \alpha_{i}}{d t_{i}}+(n-1) \frac{d \alpha_{i}}{d t_{j}}\right)\right] .
\end{aligned}
$$


This implies a marginal rate of transformation under symmetric changes of

$$
-\frac{d X_{i} / d t_{i}+(n-1) d X_{i} / d t_{j}}{d T_{i} / d t_{i}+(n-1) d T_{i} / d t_{j}}=\frac{C^{\prime \prime}\left(F_{K}-\alpha r\right)}{C^{\prime \prime}\left(F_{K}-\alpha r\right)+r t\left(F_{K} t-r\right)} .
$$

The real transformation curve under symmetry is independent of the number of countries. Furthermore, the marginal rate of transformation is larger than 1 if $r>F_{K} t \Leftrightarrow \eta<1 / n$, that is, when coordinated tax rate increases raise total debt. In this case, higher borrowing costs are associated with increasing tax rates and public good quantities. For tax rates close to 0 , this inequality should always be fulfilled. When, on the other hand, an increase in all tax rates weakens borrowing incentives, extending the public sector saves borrowing costs. Marginal costs of publicly provided goods are below pure production costs.

Since the marginal rate of transformation under symmetric coordinated changes, Equation (23), and $\left(d X_{i} / d t_{i}\right) /\left(d T_{i} / d t i\right)$ do not coincide, the outcome of tax competition is inefficient. The private consumption externality

$$
\mathrm{PCE}^{S A}=\frac{(1-\alpha) K(n-1)\left(F_{K}-\alpha r\right) t}{n(1-t)(1-\alpha t)}
$$

is positive, but the public good externality $\mathrm{PGE}^{S A}$ is ambiguous in sign. On the one hand, a unilateral tax rate increase raises the stock of capital abroad and reduces tax deductions in other countries by reducing the interest rate and the leverage ratio. On the other hand, an increase in country i's tax rate by shifting capital abroad reduces the marginal product of capital in all other countries, thereby reducing the tax base. The latter effect turns out be sufficiently small. Further calculations show that

$$
\begin{aligned}
- & \frac{d X_{i} / d t_{i}}{d T_{i} / d t_{i}}-\left[-\frac{d X_{i} / d t_{i}+(n-1) d X_{i} / d t_{j}}{d T_{i} / d t_{i}+(n-1) d T_{i} / d t_{j}}\right] \\
& =-\frac{\left.C^{\prime \prime}(n-1)\left(F_{K}-\alpha r\right) t(1-\alpha t)\left(C^{\prime \prime}\left(F_{K}-\alpha r\right)^{2}+F_{K K} K r\left(r-F_{K}\right) t\right)\right)}{\Psi\left[C^{\prime \prime}\left(F_{K}-\alpha r\right)+r t\left(F_{K} t-r\right)\right]} .
\end{aligned}
$$

Taking into account that $\Psi$ is negative, the whole term is positive provided that the marginal rate of transformation under symmetric coordinated changes is positive. However, the Nash equilibrium must be on the left-hand side of the Laffer curve, since otherwise Equation (40) would be negative, implying that each jurisdiction taxes on the downwardsloping part of the perceived Laffer curve, which would contradict the assumption of welfare-maximizing behavior. Hence, the perceived marginal rate of transformation exceeds the true marginal rate of transformation. As a consequence, all jurisdictions would 


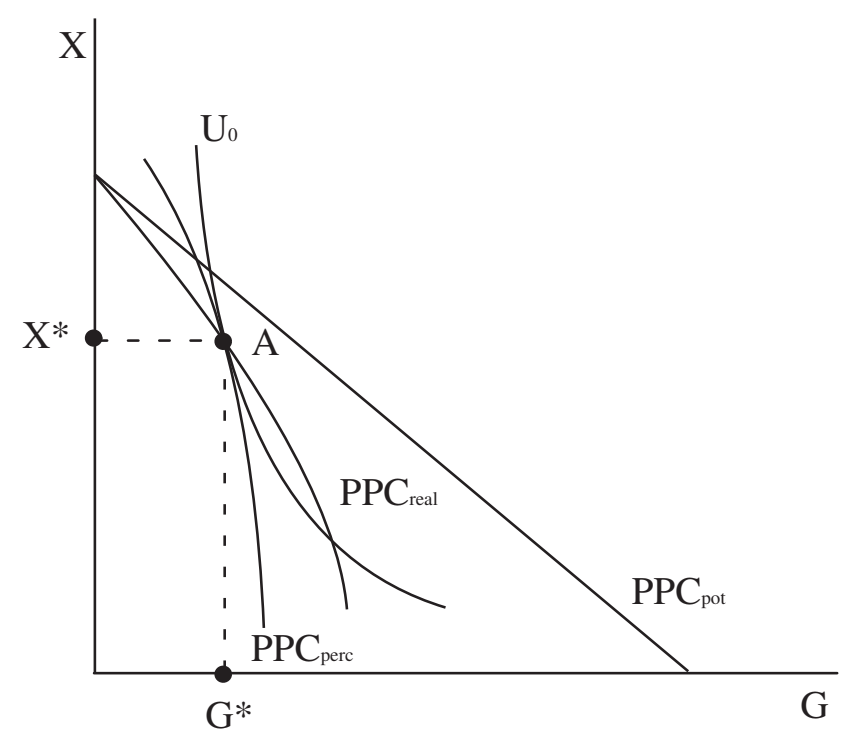

Figure 1: Underprovision of publicly provided goods

benefit from coordinated increases in tax rates and publicly provided good. The proposition summarizes this result:

Proposition 1 Under separate accounting, the symmetric Nash equilibrium of tax competition is characterized by underprovision of publicly provided goods. All jurisdictions would benefit from small increases in tax rates and public good quantities.

The findings are illustrated by Figure 1. The figure shows private and public good quantities in a representative jurisdiction in the full symmetric setting. The potential production possibility curve is depicted as $\mathrm{PPC}_{\text {pot }}$ with slope -1 and would be attainable under a hypothetical fully efficient tax system. However, since costs of equity are not deductible under corporate taxation, even with full coordination, the production possibility curve lies below the potential curve. The transformation curve under coordination is labeled $\mathrm{PPC}_{\text {real }}$. In the tax competition game, non-cooperatively taxing governments perceive higher marginal costs of tax rate increases, since they expect capital flight and other financial reactions in response to unilateral tax changes. The perceived transformation curve is indicated by $\mathrm{PPC}_{\text {perc }}$. Equation (40) shows that the perceived transformation curve is steeper than the real transformation curve, as shown in Figure 1. The symmetric 
Nash equilibrium $\left(X^{*}, G^{*}\right)$, where the perceived transformation curve and an indifference curve have the same slope, clearly lies on the real production possibility curve. Starting at this equilibrium, jurisdictions would benefit from moving along the real production possibility curve toward a larger quantity of publicly provided goods. In Figure 1 it is assumed that the real production possibility curve is always steeper than the potential production possibility curve, but this would only hold when coordinated tax rate changes increase total borrowing. However, allowing for convex parts of the production possibility curve would not have any qualitative effect on the underprovision result.

\section{Formula apportionment}

Market equilibrium Under formula apportionment, the MNE faces a uniform tax rate $\tau$ independent of investment location. Hence, it solves

$$
\max _{K_{i}, L_{i}, D_{i}} \Pi^{F A}:=\sum_{j=1}^{n}\left(\pi_{j}-\tau \pi_{j}^{t}\right) \quad \text { s.t. } E_{i} \geq 0, \quad i=1, \ldots, n .
$$

Tax bases are consolidated and distributed to jurisdictions according to a formula based on the capital share $K_{i} / \sum_{j} K_{j}$, the sales share $F\left(K_{i}, L_{i}\right) / \sum_{j} F\left(K_{j}, L_{j}\right)$, and the payroll share $w_{i} \bar{L} / \sum_{j} w_{j} \bar{L}$. Jurisdiction i's share in the total tax base is

$$
S^{i}=\gamma \frac{K_{i}}{\sum_{j} K_{j}}+\sigma \frac{F\left(K_{i}, L_{i}\right)}{\sum_{j} F\left(K_{j}, L_{j}\right)}+\phi \frac{w_{i} \bar{L}}{\sum_{j} w_{j} \bar{L}}, \quad i=1, \ldots, n .
$$

The weights of the capital share, the sales share and the payroll share sum up to 1: $\gamma+\sigma+\phi=1$. Hence, the jurisdictions' shares also sum up to $1: \sum_{j} S^{j}=1$. The MNE's effective tax rate is

$$
\tau=\sum_{j=1}^{n} t_{j} S^{j}=t_{i}+\sum_{j \neq i}\left(t_{j}-t_{i}\right) S^{j}
$$

The first-order conditions of the MNE's optimization problem are for $i=1, \ldots, n$

$$
\begin{aligned}
& (1-\tau)\left[F_{L}\left(K_{i}, L_{i}\right)-w_{i}\right]+\sum_{j \neq i}\left(t_{i}-t_{j}\right) S_{L_{i}}^{j} \sum_{k=1}^{n} \pi_{k}^{t}=0, \\
& \tau r-C^{\prime}\left(\alpha_{i}\right)=0 \\
& (1-\tau) F_{K}\left(K_{i}, L_{i}\right)-r-C\left(\alpha_{i}\right)+\alpha_{i} C^{\prime}\left(\alpha_{i}\right)+\sum_{j \neq i}\left(t_{i}-t_{j}\right) S_{K_{i}}^{j} \sum_{k=1}^{n} \pi_{k}^{t}=0 .
\end{aligned}
$$


Since the effective tax rate is independent of the jurisdiction, the optimum debt-to-capital ratio $\alpha$ is the same in all jurisdictions. In its decision regarding labor and capital, the MNE takes into consideration that changes in employment and capital stock affect tax base shares and, therefore, the effective tax rate. High tax rates reduce marginal benefits of employment and investment.

In a symmetric equilibrium $\tau=t_{i}=t, S^{i}=1 / n, S_{L_{j}}^{i}=-\left(\phi / L+\sigma F_{L} / F\right) / n^{2}<0, S_{K_{j}}^{i}=$ $-\left(\gamma / K+\sigma F_{K} / F\right) / n^{2}<0, S_{L_{i}}^{i}=-(n-1) S_{L_{j}}^{i}$, and $S_{K_{i}}^{i}=-(n-1) S_{K_{j}}^{i}$. Using symmetry, the first-order conditions and the market-clearing conditions imply that unilateral tax rate changes affect the interest rate and national wages just as they do under separate accounting. Hence, $d r / d t i, d w_{i} / d t_{i}$, and $d w_{i} / d t_{j}$ are determined by Equation (15). ${ }^{3}$ The remaining comparative statics in a symmetric set-up are for $i=1, \ldots, n$ and $j \neq i$

$$
\begin{aligned}
& \frac{d K_{j}}{d t_{i}}=-\frac{F_{K}-\alpha r}{n(1-t) K F_{K K}}\left(\gamma+\sigma \frac{F_{K} K}{F}\right)>0, \quad \frac{d K_{i}}{d t_{i}}=-(n-1) \frac{d K_{j}}{d t_{i}}<0, \\
& \frac{d \alpha}{d t_{i}}=\frac{r-F_{K} t}{n(1-\alpha t) C^{\prime \prime}} .
\end{aligned}
$$

If and only if $r>F_{K} t \Leftrightarrow \eta<1 / n$, a unilateral tax rate increase increases the uniform debt-to-capital ratio and therefore total debt. A negative debt externality would be associated with an increase in one jurisdiction's tax rate. The MNE would lower debt and, therefore, tax liabilities in other jurisdictions provided that interest rate changes do not overcompensate.

Plugging first-order conditions into the definitions for profits and taking linear homogeneity into account, yields

$$
\begin{aligned}
& \pi_{i}=\tau\left(F_{K}^{i}-\alpha r\right) K_{i}+\sum_{j \neq i}\left(t_{j}-t_{i}\right)\left(\frac{S_{L_{i}}^{j} L_{i}}{1-\tau}+S_{K_{i}}^{j} K_{i}\right) \sum_{k=1}^{n} \pi_{k}^{t}, \quad i=1, \ldots, n, \\
& \pi_{i}^{t}=\left(F_{K}^{i}-\alpha r\right) K_{i}+\sum_{j \neq i}\left(t_{j}-t_{i}\right) \frac{S_{L_{i}}^{j} L_{i}}{1-\tau} \sum_{k=1}^{n} \pi_{k}^{t}, \quad i=1, \ldots, n .
\end{aligned}
$$

Economic and taxable profits are non-zero; outside a symmetric equilibrium, even net profits per country are not zero. However, it can be shown that total net profits $\Pi^{F A}$ are zero. Profits and losses cancel out. Hence, even under formula apportionment, individual income consists only of capital and labor income.

\footnotetext{
${ }^{3}$ Wages react differently in the model of Eichner and Runkel (2008) because their production function is subject to decreasing returns to scale.
} 
Tax competition Since unilateral tax rate changes affect the common interest rate and national wages under formula apportionment exactly as they do under separate accounting, the impact of a single country's tax rate change on its private consumption, i.e., $d X_{i} / d t_{i}$, is the same under both tax systems. Hence, if there is a difference between the two tax competition game equilibria it must be related to tax revenue effects, $d T_{i} / d t_{i}$. Tax revenue at the symmetric equilibrium is

$$
T_{i}=t_{i} S^{i} \sum_{j=1}^{n} K_{j}\left[F_{K}\left(K_{j}, L_{j}\right)-\alpha r\right], \quad i=1, \ldots, n,
$$

implying

$$
\frac{d T_{i}}{d t_{i}}=\left(F_{K}-\alpha r\right) K\left(1+t n S_{t_{i}}^{i}\right)-t K\left(\alpha \frac{d r}{d t_{i}}+r \frac{d \alpha}{d t_{i}}\right), \quad i=1, \ldots, n,
$$

where

$$
S_{t_{i}}^{i}=\frac{1}{n K}\left(\gamma+\sigma \frac{F_{K} K}{F}\right) \frac{d K_{i}}{d t_{i}}+\frac{1}{n w} \phi \frac{d w_{i}}{d t_{i}}<0
$$

gives the impact of a country's tax rate on its share in the tax base. Any unilateral increase in the tax rate reduces the jurisdiction's share in the global tax base no matter what the weights in the formula are. Ceteris paribus, $S_{t_{i}}^{i}$ depends positively on each weight. Clearly, the capital-share weight affects $S_{t_{i}}^{i}$ more strongly than the sales share. If the tax rate elasticity of the jurisdiction's capital stock, $\left(t_{i} / K\right)\left(d K_{i} / d t_{i}\right)$, exceeds half the tax rate elasticity of the payroll, $\left(t_{i} / w_{i} \bar{L}\right)\left(d\left(w_{i} \bar{L}\right) / d t_{i}\right) / 2$, the capital share's weight is also greater than the payroll share's weight.

A unilateral increase in the tax rate reduces the tax base if it increases $\alpha r$, that is, if

$$
\alpha C^{\prime \prime}\left(F_{K}-\alpha r\right)+r\left(F_{K} t-r\right)<0,
$$

which requires a positive relationship between the a single tax rate and total debt, i.e., $r>F_{K} t$.

Although there are substantial differences in individual tax rate effects, the impact of coordinated tax rate increases is the same under the formula approach as it is under separate accounting. This is because separate accounting and formula apportionment are indistinguishable when tax rates are uniform. As a consequence, the true production possibility curve is always given by Equation (23). 
Since interest rate and wage effects of taxation are the same under both approaches, the private consumption externality is also positive: $\mathrm{PCE}^{F A}=\mathrm{PCE}^{S A}>0$. The public good externality

$$
\mathrm{PGE}^{F A}=(n-1)\left[\left(F_{K}-\alpha r\right) K t n S_{t_{i}}^{j}-t K\left(\alpha \frac{d r}{d t_{i}}+r \frac{d \alpha}{d t_{i}}\right)\right], \quad i=1, \ldots, n,
$$

where

$$
S_{t_{i}}^{j}=\frac{1}{n K}\left(\gamma+\sigma \frac{F_{K} K}{F}\right) \frac{d K_{j}}{d t_{i}}+\frac{1}{n w} \phi \frac{d w_{j}}{d t_{i}}>0
$$

is positive if a unilateral tax increase either reduces the debt-to-capital ratio or increases it only moderately, i.e., if $d \alpha / d t_{i}$ sufficiently low.

Due to these externalities, the symmetric Nash equilibrium of tax competition is generically inefficient. However, in contrast to separate accounting, overprovision could not be excluded analytically. The difference between perceived and real production possibility curve can be written as

$$
\begin{aligned}
- & \frac{d X_{i} / d t_{i}}{d T_{i} / d t_{i}}-\left[-\frac{d X_{i} / d t_{i}+(n-1) d X_{i} / d t_{j}}{d T_{i} / d t_{i}+(n-1) d T_{i} / d t_{j}}\right] \\
& =\frac{(n-1) t(1-\alpha t)\left[\frac{K \phi}{F-F_{K} K}-\frac{\left[F \gamma-F_{K} K(1-\gamma-\phi)\right]^{2}}{F^{2} F_{K K} K}\right]\left(F_{K}-\alpha r\right)^{2}+F_{K}-\alpha r+\frac{r\left(F_{K} t-r\right)}{C^{\prime \prime}}}{[n(1-\alpha t)-t(1-\alpha)]\left(F_{K}-\alpha r\right)} .
\end{aligned}
$$

If $F_{K} t>r \Leftrightarrow \eta>1 / n$, jurisdictions will clearly undersupply public goods. The underlying force is the positive public debt externality which reinforces positive externalities via the formula. A unilateral tax rate increase reduces the debt-to-capital ratio and thus increases the tax base.

The following proposition summarizes the results:

Proposition 2 Under formula apportionment, the symmetric Nash equilibrium of tax competition is generically characterized by an inefficient provision of publicly provided goods. If $\eta \geq 1 / n$, jurisdictions unambiguously undersupply public goods.

It should be stressed that even for $\eta<1 / n$ many rounds of numerical simulations for various parameters unambiguously found underprovision of public goods. Presumably, even the negative public debt externality could not change the results.

A direct comparison of the supply of public goods under separate accounting and formula apportionment in terms of exogenous parameters is generally not possible. A system change may or may not aggravate the underprovision problem. 


\section{Discussion}

In this section, I discuss the results by comparing them to the benchmark case of tax competition without profit shifting and by subsequently analyzing internal debt.

\subsection{Fixed debt-to-capital ratio}

When the debt-to-capital ratio is fixed at a uniform level in all jurisdictions, the MNE cannot use financial policy to reduce its tax burden in response to tax rate differentials. Hence, $d \alpha_{j} / d_{t_{i}} \equiv 0$ for all $i, j$. As a consequence, there is no excess burden of taxation when all jurisdictions always levy the same tax rate. The true production possibility curve $\mathrm{PPC}_{\text {real }}$ has slope -1 . However, the perceived production possibility curve under separate accounting $\mathrm{PPC}_{\text {perc }}$ in the symmetric Nash equilibrium of the tax competition game continues to be steeper since

$$
-\frac{d X_{i} / d t_{i}}{d T_{i} / d t_{i}}=\frac{F_{K K} K[t(1-\alpha)-n(1-\alpha t)]}{F_{K K} K[t(1-\alpha)-n(1-\alpha t)]-(n-1)\left(F_{K}-\alpha r\right) t(1-\alpha t)}>1 .
$$

Non-cooperatively taxing jurisdictions will undersupply public goods. Coordinated tax increases would increase welfare in all jurisdictions.

Underprovision of publicly provided goods is also the outcome of tax competition under formula apportionment when the debt-to-capital ratio is fixed. Not only is the private consumption externality positive, but also the public good externality

$$
\mathrm{PGE}^{F A \bar{\alpha}}:=(n-1) \frac{d T_{j}}{d t_{i}}=(n-1)\left[\left(F_{K}-\alpha r\right) K t n S_{t_{i}}^{j}-t K \alpha \frac{d r}{d t_{i}}\right]>0, \quad i=1, \ldots, n .
$$

Hence, autonomous jurisdictions will unambiguously undersupply public goods.

Furthermore, a purely capital-share based formula leads to particularly severe underprovision. Analytically it could be shown that an increase in the parameter $\gamma$ accompanied by a decrease in $\sigma$ leads to lower taxes and lower tax revenue at the equilibrium (see Appendix). Relocating capital reduces one to one the capital share, but has a smaller impact on the sales share. The more the formula relies on the mobile input, the fiercer competition is.

Whether underprovision will be more severe under separate accounting or under formula apportionment depends on the weights of capital, sales, and payroll in the formula. For a 
fully capital-share-based formula, i.e., for $\gamma=1$, where tax competition is fiercest, it can be shown that

$$
\left.\frac{d T_{i}}{d t_{i}}\right|_{S A \bar{\alpha}}-\left.\frac{d T_{i}}{d t_{i}}\right|_{F A \bar{\alpha}}=\frac{(n-1)\left(F_{K}-\alpha r\right) K t}{n(1-t)}>0 .
$$

Under separate accounting, there is a stronger incentive to raise taxes than under formula apportionment. Hence, introducing formula apportionment at the symmetric Nash equilibrium of the tax competition game under separate accounting would result in lower tax rates. Formula apportionment aggravates the underprovision problem. I conclude:

Proposition 3 If the leverage ratio is fixed at a uniform level, the symmetric Nash equilibrium of tax competition is characterized by underprovision of publicly provided goods regardless of whether separate accounting or formula apportionment is applied. A capital share base formula induces more severe underprovision than a sales share base formula. If the formula is purely capital share based, underprovision is even more severe under formula apportionment than under separate accounting.

\subsection{Internal debt}

Following Mintz and Smart (2004) and Schindler and Schjelderup (2008), I now consider internal debt as an explicit device for profit shifting. ${ }^{4}$ I add tax deductions for internal debt and also its costs to the analysis. The internal-debt-to-capital ratio in jurisdiction $i$ is $\beta_{i}=B_{i} / K_{i}$. Costs of internal borrowing are $Q\left(\beta_{i}\right) K_{i}$, with $Q(0)=Q^{\prime}(0)=0$, and $\lim _{\beta \rightarrow 1} Q^{\prime}(\beta)=\infty$. Costs of internal lending are $0, Q(\beta)=0$ for $\beta<0$, costs of internal borrowing positive and increasing, $Q^{\prime}(\beta) \geq 0$ and $Q^{\prime \prime}(\beta) \geq 0$ if $\beta>0$. Thin-capitalization rules are not explicitly modeled, but could be seen as part of costs of internal borrowing. Since lending is only internal, the total sum of internal debt is $0: \sum_{j=1}^{n} \beta_{j} K_{j}=0$. Economic profits and taxable profits become ${ }^{5}$

$$
\begin{aligned}
& \pi_{i}=F\left(K_{i}, L_{i}\right)-w_{i} L_{i}-\left[r+C\left(\alpha_{i}\right)+Q\left(\beta_{i}\right)\right] K_{i}, \quad i=1, \ldots, n . \\
& \pi_{i}^{t}=F\left(K_{i}, L_{i}\right)-w_{i} L_{i}-r\left(\alpha_{i}+\beta_{i}\right) K_{i}, \quad i=1, \ldots, n .
\end{aligned}
$$

\footnotetext{
${ }^{4}$ See also Haufler and Runkel (2009).

${ }^{5} \mathrm{I}$ assume that the interest rate for internal debt is the same as for external debt, there is no transferpricing issue involved. Chowdhry and Nanda (1994) have considered the external interest rate as anchor for the internal interest rate..
} 
Under separate accounting, the MNE solves

$$
\max _{K_{i}, L_{i}, D_{i}, B_{i}} \Pi^{I D}:=\sum_{j=1}^{n}\left(\pi_{j}-t_{j} \pi_{j}^{t}\right) \quad \text { s.t. } \sum_{j=1}^{n} \beta_{j} K_{j}=0 \text { and } E_{i} \geq 0, i=1, \ldots, n .
$$

First-order conditions with respect to investment and internal borrowing in jurisdiction $i$, $i=1, \ldots, n$, are

$$
\begin{aligned}
& \left(1-t_{i}\right) F_{K}\left(K_{i}, L_{i}\right)-r-C\left(\alpha_{i}\right)-Q\left(\beta_{i}\right)+\alpha_{i} C^{\prime}\left(\alpha_{i}\right)+\beta_{i} Q^{\prime}\left(\beta_{i}\right)=0 \\
& t_{i} r-Q^{\prime}\left(\beta_{i}\right)-\lambda=0,
\end{aligned}
$$

where $\lambda$ is the Lagrangian of the internal debt constraint. Denoting the lowest tax rate by $t_{m}$, the internal debt condition can be written as

$$
\left(t_{i}-t_{m}\right) r=Q^{\prime}\left(\beta_{i}\right), \quad i=1, \ldots, n
$$

The firm's affiliate in the jurisdiction with the lowest tax rate will lend to all other affiliates. The size of internal debt is mainly determined by the tax rate differential. Internal assets in the minimum tax jurisdiction are determined by the borrowing constraint: $B_{m}=-\sum_{j \neq m} B_{j}$. However, in a symmetric equilibrium, there will be no internal borrowing.

Although the calculations are slightly more complex, it can be shown that with internal borrowing, the symmetric Nash equilibrium under separate accounting is characterized by underprovision of publicly provided goods. This should not be a surprise. External debt is a substitute for internal borrowing as means of profit shifting.

Finally, since under formula apportionment, the benefits of internal debt are always zero, the MNE will not issue internal debt, regardless of the tax rates. The tax game under formula apportionment is not affected by internal debt.

\section{Concluding remarks}

This paper analyzed tax competition when welfare-maximizing jurisdictions levy sourcebased corporate taxes and multinational enterprises choose leverage ratios in a tax-efficient way. First, separate accounting, under which multinationals shift debt from low-tax to 
high-tax countries, was considered. It was shown that in this situation the Nash equilibrium of the tax competition game is characterized by underprovision of publicly provided goods. Next analyzed was formula apportionment, under which the country-specific leverage ratio of a multinational's affiliate is independent of the jurisdiction's tax rate. The paper shows that public good provision is still inefficient and characterized the inefficient outcome. Finally, it was shown that underprovision is the unambiguous outcome of tax competition if leverage ratios are fixed at a uniform level.

The model could be extended in several ways. For example, asymmetry could be introduced. Asymmetric tax competition when profit shifting is feasible has been neglected in the literature to date. Stoewhase (2005) is an exception, but he considers capital taxation instead of profit taxation. Asymmetry is studied in the literature on tax havens (see, e.g., Hong and Smart, 2007; Slemrod and Wilson, 2006). Another extension could involve considering the deductible share as a policy variable, as Pinto (2007) has done.

Acknowledgement The paper was presented at the CESifo Public Sector Economics conference in 2010 and at a research seminar at the University of Magdeburg. Many thanks to Nadine Riedel and the participants. The usual disclaimer applies. 


\section{Appendix}

Setting $\sigma=1-\gamma-\phi$, the impact of an increase in $\gamma$ on $G_{i}=T_{i} / L$ could be written as

$$
\frac{d G_{i}}{d \gamma}=\left(S^{i}+t_{i} S_{t_{i}}^{i}\right) \frac{\sum_{j=1}^{n} K_{j} F_{K}^{j}}{L} \frac{d t_{i}}{d \gamma}
$$

when $\partial S^{i} / \partial \gamma=0$ is taken into account.

Since $S^{i}+t_{i} S_{t_{i}}^{i}>0, \operatorname{sign}\left(d G_{i} / d \gamma\right)=\operatorname{sign}\left(d t_{i} / d \gamma\right)$. Denoting country $i^{\prime} s$ welfare by $V_{i}\left(t_{i}, t_{j}\right)$, from the first-order conditions of the Nash equilibrium, the impact on tax rates of changes in $\gamma$ could be calculated:

$$
\frac{d t_{i}}{d \gamma}=-\frac{\frac{\partial^{2} V_{i}}{\partial t_{i} \partial \gamma} \frac{d^{2} V_{j}}{d t_{j}^{2}}-\frac{\partial^{2} V_{i}}{\partial t_{i} \partial t_{j}} \frac{\partial^{2} V_{j}}{\partial t_{j} \partial \gamma}}{\Delta}, \quad i=1,2, j \neq i
$$

where

$$
\Delta=\frac{\partial^{2} V_{i}}{\partial t_{i}^{2}} \frac{\partial^{2} V_{j}}{\partial t_{j}^{2}}-\frac{\partial^{2} V_{i}}{\partial t_{i} \partial t_{j}} \frac{\partial^{2} V_{j}}{\partial t_{j} \partial t_{i}}
$$

Using symmetry, this can be written as

$$
\frac{d t_{i}}{d \gamma}=-\frac{\frac{\partial^{2} V_{i}}{\partial t_{i} \partial \gamma}}{\frac{\partial^{2} V_{i}}{\partial t_{i}^{2}}+\frac{\partial^{2} V_{i}}{\partial t_{i} \partial t_{j}}}, \quad i=1,2, j \neq i
$$

Stability of the Nash equilibrium implies

$$
\frac{d t_{i}}{d \gamma}<0 \quad \text { if and only if } \quad \frac{\partial^{2} V_{i}}{\partial t_{i} \partial \gamma}<0, \quad i=1,2
$$

Furthermore, for $i=1,2$,

$$
\frac{\partial^{2} V_{i}}{\partial t_{i} \partial \gamma}=\frac{\sum_{j=1}^{n} K_{j} F_{K}^{j}}{L}\left[\frac{\partial S^{i}}{\partial \gamma}\left(U_{X G} t_{i} \frac{d X_{i}}{d t_{i}}+\frac{U_{G G} t_{i}}{L} \frac{d T_{i}}{d t_{i}}+U_{G}\right)+U_{G} t_{i} \frac{\partial^{2} S^{i}}{\partial \partial t_{i} \gamma}\right] .
$$

Together with

$$
\frac{\partial S^{i}}{\partial \gamma}=0 \quad \text { and } \quad \frac{\partial^{2} S^{i}}{\partial t_{i} \partial \gamma}=\frac{1}{2} \frac{d K_{i}}{d t_{i}}\left(\frac{F-F_{K} K}{K F}\right)<0,
$$

this implies that $d t_{i} / d \gamma$ and $d T_{i} / d \gamma$ are negative. 


\section{References}

Bucovetsky, S., And J. Wilson (1991): "Tax Competition with Two Tax Instruments," Regional Science and Urban Economics, 21, 333-350.

Chowdhry, B., AND V. NANDA (1994): "Financing of Multinational Subsidiaries: Parental Debt vs. External Debt," Journal of Corporate Finance, 1, 259-281.

Desai, M., F. Foley, and J. Hines (2004): "A Multinational Perspective on Capital Structure Choice and Internal Capital Markets," Journal of Finance, 59, 2451-2488.

Devereux, M. P. (2006): "The Impact of Taxation on the Location of Capital, Firms and Profit: A Survey of Empirical Evidence," Oxford University Centre for Business Taxation Working Paper, 07/02.

Dischinger, M. (2007): "Profit Shifting by Multinationals: Indirect Evidence from European Micro Data," University of Munich Discussion Paper, 30.

Egger, P., W. Eggert, C. Keuschnigg, and H. Winner (2009): "Corporate Taxation, Debt Financing and Foreign Plant Ownership," European Economic Review, in press.

EgGert, W., and W. Schjelderup (2003): "Symmetric Tax Competition Under Formual Apportionment," Journal of Public Economic Theory, 5, 439-446.

EichneR, T., And M. Runkel (2008): "Corporate Income Taxation of Multinationals in a General Equilibrium Model," CESifo Working Paper, 2320.

European Commission (2001): "Company Taxation in the Internal Market," Discussion paper.

Fuest, C. (2008): “The European Commission's Proposal for a Common Consolidated Coporate Tax Base," Oxford University Center for Business Taxation Working Paper, $08 / 23$.

Haufler, A., And M. Runkel (2009): "Firms' Financial Choices and Thin Capitalization Rules under Corporate Tax Competition," Working Paper. 
Haufler, A., and G. Schjelderup (2000): "Corporate Tax Systems and Cross Country Profit Shifting," Oxford Economic Papers, 52, 306-325.

Hong, Q., And M. Smart (2007): "In Praise of Tax Havens: International Tax Planning and Foreign Direct Investment," CESifo Working Paper, 1942.

Huizinga, H., And L. Laeven (2008): "International Profit Shifting within Multinationals: A Multi-Country Perspective," Journal of Public Economics, 92, 1164-1182.

Huizinga, H., L. Laeven, and G. Nicodeme (2008): "Capital Structure and International Debt Shifting," Journal of Financial Economics, 88, 80-118.

Kolmar, M., And A. Wagener (2007): "Tax Competition with Formula Apportionment: The Interaction Between Tax Base and Sharing Mechanism," CESifo Working Paper, 2097.

Mintz, J., And M. Smart (2004): "Income Shifting, Investment, and Tax Competition: Theory and Evidence from Provincial Taxation in Canada," Journal of Public Economics, 88, 1149-1168.

Nielsen, S., P. Raimondos-Moeller, and G. Schjelderup (2010): "Company Taxation and Tax Spillovers: Separate Accounting Versus Formula Apportionment," European Economic Review, 54, 121-132.

Overesch, M. (2009): "The Effects of Multinationals Profit Shifting Activities on Real Investments," National Tax Journal, 62, 5-23.

Pethig, R., and A. Wagener (2007): "Profit Tax Competition and Formula Apportionment," International Tax and Public Finance, 14, 631-655.

Pinto, S. (2007): "Corporate Profit Tax, Capital Mobility, and Formula Apportionment," Journal of Urban Economics, 62, 76-102.

Riedel, N., And M. Runkel (2007): "Company Tax Reform with a Water's Edge," Journal of Public Economics, 91, 1533-1554. 
Schindler, D., And G. Schjelderup (2008): "Multinationals, Minority Ownership and Tax-Efficient Financing Structures," Norwegian School of Economics and Business Administration Discussion Paper, 19.

Slemrod, S., And J. Wilson (2006): "Tax Competition and Parasitic Tax Havens," NBER Working Paper, 12225.

Stoewhase, S. (2005): "Asymmetric Capital Tax Competition with Profit Shifting," Journal of Economics, 85, 175-196.

Weichenrieder, A. (2009): "Profit Shifting in the EU: Evidence from Germany," International Taxation and Public Finance, 16, 281-297.

Wellisch, D. (2004): "Taxation Under Formula Apportionment - Tax Competition, Tax Incidence, and the Choice of Apportionment Factors," FinanzArchiv, 60, 24-41.

Zodrow, G., And P. Mieszkowski (1986): "Pigou, Tiebout, Property Taxation, and the Underprovision of Local Public Goods," Journal of Urban Economics, 19, 356-370. 


\section{CESifo Working Paper Series}

for full list see www.cesifo-group.org/wp

(address: Poschingerstr. 5, 81679 Munich, Germany, office@cesifo.de)

2977 Johann K. Brunner and Susanne Pech, Optimum Taxation of Bequests in a Model with Initial Wealth, March 2010

2978 Guglielmo Maria Caporale and Nicola Spagnolo, Stock Market Integration between three CEECs, Russia and the UK, March 2010

2979 Florian Englmaier, Ales Filipi and Ravi Singh, Incentives, Reputation and the Allocation of Authority, March 2010

2980 Konstantinos Angelopoulos, George Economides and Apostolis Philippopoulos, What is the Best Environmental Policy? Taxes, Permits and Rules under Economic and Environmental Uncertainty, March 2010

2981 Frederick van der Ploeg, Rapacious Resource Depletion, Excessive Investment and Insecure Property Rights, March 2010

2982 Wolfram F. Richter and Christoph Braun, Efficient Subsidization of Human Capital Accumulation with Overlapping Generations and Endogenous Growth, March 2010

2983 Francesco Cinnirella, Marc Piopiunik and Joachim Winter, Why Does Height Matter for Educational Attainment? Evidence from German Pre-Teen Children, March 2010

2984 Bernard Van Praag, Well-being Inequality and Reference Groups - An Agenda for New Research, March 2010

2985 Francesca Barion, Raffaele Miniaci, Paolo M. Panteghini and Maria Laura Parisi, Profit Shifting by Debt Financing in Europe, March 2010

2986 Alexander Haupt and Magdalena Stadejek, The Choice of Environmental Policy Instruments: Energy Efficiency and Redistribution, March 2010

2987 John Komlos and Marek Brabec, The Trend of BMI Values among US Adults, March 2010

2988 Emanuele Massetti and Lea Nicita, The Optimal Climate Policy Portfolio when Knowledge Spills across Sectors, March 2010

2989 Helmut Rainer and Thomas Siedler, Family Location and Caregiving Patterns from an International Perspective, March 2010

2990 Toru Kikuchi and Ngo Van Long, A Simple Model of Service Offshoring with Time Zone Differences, March 2010

2991 Assaf Razin, Efraim Sadka and Benjarong Suwankiri, Migration and the Welfare State: Dynamic Political-Economy Theory, March 2010 
2992 Bård Harstad, Buy Coal! Deposit Markets Prevent Carbon Leakage, March 2010

2993 Axel Dreher, Stephan Klasen, James Raymond Vreeland and Eric Werker, The Costs of Favoritism: Is Politically-driven Aid less Effective?, March 2010

2994 Sven Neelsen and Thomas Stratmann, Effects of Prenatal and Early Life Malnutrition: Evidence from the Greek Famine, March 2010

2995 Claude Hillinger and Bernd Süssmuth, The Quantity Theory of Money: An Assessment of its Real Linchpin Prediction, March 2010

2996 Matthew M. Chingos and Martin R. West, Do More Effective Teachers Earn More Outside of the Classroom?, March 2010

2997 Laurence Jacquet and Dirk Van de gaer, A Comparison of Optimal Tax Policies when Compensation or Responsibility Matter, March 2010

2998 Valentina Bosetti, Carlo Carraro, Romain Duval and Massimo Tavoni, What Should we Expect from Innovation? A Model-Based Assessment of the Environmental and Mitigation Cost Implications of Climate-Related R\&D, March 2010

2999 Scott Alan Carson, Nineteenth Century Stature and Family Size: Binding Constraint or Productive Labor Force?, March 2010

3000 Jukka Pirttilä and Ilpo Suoniemi, Public Provision, Commodity Demand and Hours of Work: An Empirical Analysis, March 2010

3001 Bertrand Candelon and Franz C. Palm, Banking and Debt Crises in Europe: The Dangerous Liaisons?, March 2010

3002 Joan Costa-i-Font and Marin Gemmill-Toyama, Does Cost Sharing really Reduce Inappropriate Prescriptions?, March 2010

3003 Scott Barrett, Climate Treaties and Backstop Technologies, March 2010

3004 Hans Jarle Kind, Tore Nilssen and Lars Sørgard, Price Coordination in Two-Sided Markets: Competition in the TV Industry, March 2010

3005 Jay Pil Choi and Heiko Gerlach, Global Cartels, Leniency Programs and International Antitrust Cooperation, March 2010

3006 Aneta Hryckiewicz and Oskar Kowalewski, Why do Foreign Banks Withdraw from other Countries? A Panel Data Analysis, March 2010

3007 Eric A. Hanushek and Ludger Woessmann, Sample Selectivity and the Validity of International Student Achievement Tests in Economic Research, March 2010

3008 Dennis Novy, International Trade and Monopolistic Competition without CES: Estimating Translog Gravity, April 2010 
3009 Yin-Wong Cheung, Guonan Ma and Robert N. McCauley, Renminbising China's Foreign Assets, April 2010

3010 Michel Beine and Sara Salomone, Migration and Networks: Does Education Matter more than Gender?, April 2010

3011 Friedrich Schneider, Tilman Brück and Daniel Meierrieks, The Economics of Terrorism and Counter-Terrorism: A Survey (Part I), April 2010

3012 Friedrich Schneider, Tilman Brück and Daniel Meierrieks, The Economics of Terrorism and Counter-Terrorism: A Survey (Part II), April 2010

3013 Frederick van der Ploeg and Steven Poelhekke, The Pungent Smell of "Red Herrings": Subsoil Assets, Rents, Volatility and the Resource Curse, April 2010

3014 Vjollca Sadiraj, Jan Tuinstra and Frans van Winden, Identification of Voters with Interest Groups Improves the Electoral Chances of the Challenger, April 2010

3015 Guglielmo Maria Caporale, Davide Ciferri and Alessandro Girardi, Time-Varying Spot and Futures Oil Price Dynamics, April 2010

3016 Scott Alan Carson, Racial Differences in Body-Mass Indices for Men Imprisoned in $19^{\text {th }}$ Century US Prisons: A Multinomial Approach, April 2010

3017 Alessandro Fedele, Paolo M. Panteghini and Sergio Vergalli, Optimal Investment and Financial Strategies under Tax Rate Uncertainty, April 2010

3018 Laurence Jacquet, Take it or Leave it: Take-up, Optimal Transfer Programs, and Monitoring, April 2010

3019 Wilhelm Kohler and Jens Wrona, Offshoring Tasks, yet Creating Jobs?, April 2010

3020 Paul De Grauwe, Top-Down versus Bottom-Up Macroeconomics, April 2010

3021 Karl Ove Aarbu, Demand Patterns for Treatment Insurance in Norway, April 2010

3022 Toke S. Aidt and Jayasri Dutta, Fiscal Federalism and Electoral Accountability, April 2010

3023 Bahram Pesaran and M. Hashem Pesaran, Conditional Volatility and Correlations of Weekly Returns and the VaR Analysis of 2008 Stock Market Crash, April 2010

3024 Stefan Buehler and Dennis L. Gärtner, Making Sense of Non-Binding Retail-Price Recommendations, April 2010

3025 Leonid V. Azarnert, Immigration, Fertility, and Human Capital: A Model of Economic Decline of the West, April 2010

3026 Christian Bayer and Klaus Wälde, Matching and Saving in Continuous Time: Theory and 3026-A Matching and Saving in Continuous Time: Proofs, April 2010 
3027 Coen N. Teulings and Nick Zubanov, Is Economic Recovery a Myth? Robust Estimation of Impulse Responses, April 2010

3028 Clara Graziano and Annalisa Luporini, Optimal Delegation when the Large Shareholder has Multiple Tasks, April 2010

3029 Erik Snowberg and Justin Wolfers, Explaining the Favorite-Longshot Bias: Is it RiskLove or Misperceptions?, April 2010

3030 Doina Radulescu, The Effects of a Bonus Tax on Manager Compensation and Welfare, April 2010

3031 Helmut Lütkepohl, Forecasting Nonlinear Aggregates and Aggregates with Timevarying Weights, April 2010

3032 Silvia Rocha-Akis and Ronnie Schöb, Welfare Policy in the Presence of Unionised Labour and Internationally Mobile Firms, April 2010

3033 Steven Brakman, Robert Inklaar and Charles van Marrewijk, Structural Change in OECD Comparative Advantage, April 2010

3034 Dirk Schindler and Guttorm Schjelderup, Multinationals, Minority Ownership and TaxEfficient Financing Structures, April 2010

3035 Christian Lessmann and Gunther Markwardt, Decentralization and Foreign Aid Effectiveness: Do Aid Modality and Federal Design Matter in Poverty Alleviation?, April 2010

3036 Eva Deuchert and Conny Wunsch, Evaluating Nationwide Health Interventions when Standard Before-After Doesn't Work: Malawi’s ITN Distribution Program, April 2010

3037 Eric A. Hanushek and Ludger Woessmann, The Economics of International Differences in Educational Achievement, April 2010

3038 Frederick van der Ploeg, Aggressive Oil Extraction and Precautionary Saving: Coping with Volatility, April 2010

3039 Ainura Uzagalieva, Evžen Kočenda and Antonio Menezes, Technological Imitation and Innovation in New European Union Markets, April 2010

3040 Nicolas Sauter, Jan Walliser and Joachim Winter, Tax Incentives, Bequest Motives, and the Demand for Life Insurance: Evidence from two Natural Experiments in Germany, April 2010

3041 Matthias Wrede, Multinational Capital Structure and Tax Competition, April 2010 